\title{
Bias toward Use of a Specific T Cell Receptor $\beta$-chain Variable Region in a Subgroup of Individuals with Sarcoidosis
}

\author{
David R. Moller, Kazuki Konishi, Martha Kirby, Bruno Balbi, and Ronald G. Crystal \\ Pulmonary Branch, National Heart, Lung, and Blood Institute, National Institutes of Health, Bethesda, Maryland 20892
}

\begin{abstract}
To evaluate the concept that biases in the usage of $T$ cell antigen receptor $\beta$ variable $(V)$ regions may be manifested in $T$ lymphocytes that accumulate in nonmalignant, $T$ cell-mediated human disorders, a $V_{\beta} 8$-specific antibody (anti- $T_{i 3 \Lambda}$, 5REX9H5) was used to evaluate lung and blood $T$ cells in pulmonary sarcoidosis, a chronic granulomatous disorder of unknown etiology. Whereas normal patients had $<5 \% \mathrm{~T}_{\mathbf{B A}^{+}}$ lung $(n=7)$ and/or blood $(n=9)$ lymphocytes, strikingly, a subgroup (8 of 21 ) with active pulmonary sarcoidosis had $>7 \%$ $T_{13 A^{+}}$lung and/or blood $T$ cells and a higher proportion of $\mathbf{T}_{\mathbf{3 B}}{ }^{+}$ lymphocytes in the lung compared with blood. Dual-color flow cytometry demonstrated compartmentalization of $\mathrm{T}_{\mathrm{BBA}} \mathrm{CD4}^{+}$ lymphocytes to lung and $\mathrm{T}_{\mathrm{iBA}} \mathrm{CD8}^{+}$lymphocytes to blood. Analysis with a ${ }^{32} \mathrm{P}$-labeled $\mathrm{V}_{\beta} 8$ probe revealed that sarcoid lung $T$ lymphocytes contained higher amounts of $\mathrm{V}_{\beta} 8^{+}$mRNA than autologous blood $T$ cells. However, Southern analysis of sarcoid lung and blood $T$ cell DNA demonstrated no evidence of clonal rearrangements of $\mathrm{V}_{\beta} 8$ genes. These observations demonstrate a clear bias toward the use of at least one $V_{\beta}$ region in sarcoidosis, and suggests $T$ cells accumulate secondary to external selective pressure, rather than in a random polyclonal fashion or by clonal expansion of one or few $T$ cell clones.
\end{abstract}

\section{Introduction}

The specificity of the T lymphocyte for an antigen presented in the context of class I and II MHC proteins resides with the T cell receptor, a dimeric complex of a $50-\mathrm{kD} \alpha$-chain and 43-kD $\beta$-chain (1-4). The enormous diversity of $T$ cell specificities is created by rearrangement, during $T$ cell ontogeny, of germline variable $(\mathrm{V})^{1}$, diversity (D), junctional $(\mathrm{J})$, and constant $(\mathrm{C})$ region DNA segments of the genes coding for the $T$ cell receptor (5-7). Recent estimates suggest there are $>50 \mathrm{~V}_{\alpha}$ and $50 \mathrm{~J}_{\alpha}$ gene segments and at least $60 \mathrm{~V}_{\beta}, 2 \mathrm{D}_{\beta}$, and $13 \mathrm{~J}_{\beta}$ segments $(8$, 9), a repertoire of genetic building blocks apparently sufficient for the necessary $T$ cell antigen specificities.

Address reprint requests to Pulmonary Branch, Building 10, Room 6D03, National Heart, Blood, and Lung Institute, National Institutes of Health, Bethesda, MD 20892.

Received for publication 29 December 1987 and in revised form 20 May 1988.

1. Abbreviations used in this paper: $\mathrm{C}$, constant region; $\mathrm{D}$, diversity region; FITC, fluorescein isothiocyanate; J, junctional region; V, variable region.

J. Clin. Invest.

(c) The American Society for Clinical Investigation, Inc.

0021-9738/88/10/1183/09 \$2.00

Volume 82, October 1988, 1183-1191
Despite this potential broad diversity, studies in experimental animals suggest there can be biases in the use of specific germline genetic elements that make up the $\mathrm{T}$ cell antigen receptor variable regions. In this context, significant preferences have been observed in the usage of specific $V$ regions for $\alpha\left(V_{\alpha}\right)$ and $\beta\left(V_{\beta}\right)$ chains by $T$ cells responsive to defined antigen-MHC or allogenic determinants (10-14). It also has been suggested that $\mathrm{T}$ cells with specific antigen receptor repertoires may accumulate in association with normal and abnormal developmental processes (15-19) or may be expanded or restricted by $\mathrm{T}$ cell-T cell interactions and/or anti-T cell receptor antibodies, in a fashion analogous to the network interactions in $B$ cell immune responses (20).

Identification of biases in the usage of specific $T$ cell antigen receptor gene elements is not only of interest in terms of the general understanding of $T$ cell-mediated immune responses. It also may help us to understand $\mathrm{T}$ cell-mediated human diseases of unknown etiology by offering clues to the nature of the stimulus or to regulatory processes that contribute to the overall pathogenic process. One such disease is sarcoidosis, a common, nonmalignant, chronic disorder of unknown etiology characterized at sites of disease by the enhanced accumulation of $\mathrm{CD}^{+} \mathrm{T}$ cells, exaggerated $\mathrm{T}$ cell proliferation, and the spontaneous expression of the IL 2 and IL 2 receptor genes, and noncaseating granuloma (21-30). In the context of these considerations, evaluation of the $T$ cells that accumulate at sites of disease in sarcoidosis for a possible bias in the usage of genetic units that can code for the elements of the $\mathrm{T}$ cell antigen receptor variable regions may provide insights into the specificity and function of $\mathrm{T}$ cells in the disease process.

As an initial approach to this concept, we have evaluated sarcoid lung and blood $T$ cell populations for usage of the $V_{\beta} 8$ subfamily of $T_{\beta}$ variable regions. We focused on $V_{\beta} 8$ after a preliminary screen with a panel of $T$ cell clonotype-specific antibodies demonstrated a striking bias for $\mathrm{T}$ cells expressing $\mathrm{V}_{\beta} 8$ surface determinants in a subgroup of individuals with this disease.

\section{Methods}

Study populations. Using previously defined criteria, including lung biopsy, bronchoalveolar lavage, and gallium-67 lung scanning $(21,31)$ the diagnosis of active pulmonary sarcoidosis was established in 21 individuals. None were receiving therapy at the time of study or within the previous $2 \mathrm{mo}$. As is typical for such patients $(21,32)$, the average proportion of lymphocytes in the lavage fluid was elevated $(58 \pm 4 \%$ [all data are presented as mean $\pm \mathrm{SEM}$ ), as was the ratio of $\mathrm{CD}^{+}$(helper/ inducer) to $\mathrm{CD}^{+}$(suppressor/cytotoxic) $\mathrm{T}$ cells $(6.6 \pm 1.1)$, whereas the $\mathrm{CD}^{+} / \mathrm{CD}^{+}$ratio for blood $\mathrm{T}$ lymphocytes averaged $1.3 \pm 0.2$. For comparison, nine normal individuals were evaluated who had no history of lung disease and who had normal physical examinations, chest $x$ rays, and lung function tests. As is typical for normal individuals (29, 32), bronchoalveolar lavage revealed lymphocytes representing $19 \pm 2 \%$ of the recovered cells with a $\mathrm{CD}^{+} / \mathrm{CD}^{+}$ratio of $2.0 \pm 0.2$, whereas the 
$\mathrm{CD}^{+} / \mathrm{CD}^{+}$ratio for blood $\mathrm{T}$ lymphocytes averaged $1.7 \pm 0.2$. For comparison purposes, six additional individuals with lung $\mathrm{T}$ cell disorders were evaluated, the disorders including hypersensitivity pneumonitis $(n=3)$ and berylliosis $(n=3)$. These individuals had findings typical for each disease, respectively, as previously described (33-35).

Source and purification of cells. Lung mononuclear cells obtained by bronchoalveolar lavage (29) were enriched for T lymphocytes by passage over nylon wool columns (36). Blood mononuclear cells, isolated using Ficoll-Hypaque, were enriched for $\mathrm{T}$ lymphocytes in a similar fashion. In all cases, the resulting lung lymphocyte preparations were $>70 \% \mathrm{~T}$ lymphocytes and the blood lymphocytes were $>90 \% \mathrm{~T}$ cells, as assessed by the pan-T MAb, anti-CD2 (see below). Blood neutrophils were isolated from the cell pellets of the Ficoll-Hypaque gradients using high-molecular weight dextran sedimentation. Control T lymphocyte cell lines CCRF-CEM (American Type Culture Collection, Rockville, MD) and Jurkat (37) were grown in RPMI containing $10 \%$ FCS.

Monoclonal antibodies. The antibodies used to define $T$ cells and $T$ cell subtypes included anti-CD2 (pan-T cell; unconjugated [Leu5; Becton, Dickinson \& Co., Oxnard, CA] or conjugated with biotin [ $\mathrm{T}_{11}$-biotin; Coulter Immunology, Coulter Electronics, Inc., Hialeah, FL]); anti-CD3 (anti- $\mathrm{T}_{3}$; unconjugated [Leu4, Becton, Dickinson \& Co.]); anti-CD4 (helper/inducer T cell; unconjugated [Leu3, Becton, Dickinson \& Co.] or conjugated with biotin [Leu3-biotin; Becton, Dickinson \& Co.]); and anti-CD8 (suppressor/cytotoxic T cell; unconjugated [Leu2, Becton, Dickinson \& Co.] or conjugated with biotin [Leu2-biotin, Becton, Dickinson \& Co.]). The antibodies used in the preliminary screen (carried out as described for anti- $\mathrm{T}_{\mathrm{i} 3 \mathrm{~A}}$, see below) for a possible bias in the use of specific $T$ cell antigen receptors in sarcoidosis included: 42-1C1, an anticlonotypic MAb directed against the HPB-ALL T cell tumor line (38) (kindly provided by A. Boylston, St. Mary's Hospital Medical School, London, England); A2, S5, and D6 anticlonotypic MAb directed against the HPB-MLT T cell tumor line (kindly provided by S. Ip, T-cell Sciences, Cambridge, MA) and anti- $T_{\mathrm{i} 3 \mathrm{~A}}$ [5REX9H5, an anticlonotypic antibody directed against the REX T cell tumor line (kindly provided by E. Reinherz, Dana-Farber Cancer Institute, Boston, MA). This antibody specifically binds to an epitope on the human $T$ cell antigen receptor $\beta$ chain coded by $V_{\beta} 8$ gene subfamily chains $(39,40)$. After a preliminary screen demonstrated a striking bias in sarcoidosis toward the use of the $V_{\beta} 8$ gene subfamily as identified by anti- $T_{i 3 A}$, all subsequent studies focused on this antibody.

The various antibodies were identified by immunofluorescence using: fluorescein-conjugated goat anti-mouse Ig (FITC-anti-mouse Ig; Becton, Dickinson \& Co.) and avidin-conjugated Texas Red fluorochrome (avidin-Texas Red; Cappel Laboratories, Malvern, PA). Control antibodies included unconjugated, nonrelevant mouse myeloma antibodies (control-Ig; Cappel Laboratories), and nonrelevant isotype matched mouse myeloma antibodies conjugated with biotin (biotin-control-Ig; Litton Bionetics, Kensington, MD).

Immunofluorescence and flow cytometry. Single-color immunofluorescence and two-color immunofluorescence multiparameter flow cytometry was carried out using a dual laser fluorescence-activated cell sorter system (FACS 440; Becton, Dickinson \& Co.) with an argon laser $(488 \mathrm{~nm})$ and a krypton laser $(568 \mathrm{~nm})$ as previously described (29). For single-color, indirect immunofluorescence, lung and blood lymphocytes were incubated $\left(20 \mathrm{~min}\right.$ at $\left.4^{\circ} \mathrm{C}\right)$ with $10 \%$ normal human AB sera (Biocell Laboratories, Carson, CA) plus $10 \%$ goat sera (Cappel Laboratories), washed, and then incubated $\left(30 \mathrm{~min}\right.$ at $\left.4^{\circ} \mathrm{C}\right)$ with antiCD2 (Leu5), anti-CD3 (Leu4), anti-CD4 (Leu3), anti-CD8 (Leu2), or anti- $T_{i 3 A}$ followed by FITC-anti-mouse Ig as the second reagent. Isotype-matched, nonrelevant mouse myeloma antibodies stained with FITC-anti-mouse Ig were used to assess nonspecific immunofluorescence.

For two-color, indirect immunofluorescence evaluation of anti$\mathrm{T}_{\mathrm{i3}} \mathrm{A}^{+}$cells, the cells were first incubated in $10 \%$ normal human sera plus $10 \%$ goat sera $\left(15 \mathrm{~min}\right.$ at $\left.4^{\circ} \mathrm{C}\right)$ and then incubated $\left(30 \mathrm{~min}\right.$ at $4^{\circ} \mathrm{C}$ ) with unconjugated anti- $\mathrm{T}_{\mathrm{i} 3 \mathrm{~A}}$ or control-Ig followed by FITC-anti- mouse Ig. The cells were then washed, incubated $\left(25 \mathrm{~min}\right.$ at $\left.4^{\circ} \mathrm{C}\right)$ with $50 \%$ mouse sera (Cappel Laboratories), washed, and further incubated (30 min at $4^{\circ} \mathrm{C}$ ) with one of the following biotin-conjugated antibodies: biotin-anti-CD2 ( $T_{11}$-biotin), biotin-anti-CD4 (Leu3-biotin), biotin-anti-CD8 (Leu2-biotin), or biotin-labeled, isotype-matched, nonrelevant mouse myeloma antibodies (biotin-control-Ig). The cells were then stained with avidin-Texas Red $\left(30 \mathrm{~min}\right.$ at $\left.4^{\circ} \mathrm{C}\right)$. To assess possible nonspecific immunofluorescence resulting from an interaction between the biotinylated MAb and FITC-anti-mouse Ig, additional controls included cells incubated with control-Ig stained by FITC-anti-mouse Ig, further incubated with either biotin-anti-CD2, biotin-anti-CD4, or biotin-anti-CD8 and subsequently stained with avidin-Texas Red. All cells stained for two-color immunofluorescence had parallel evaluations of cells stained for anti-CD2, anti-CD4, anti-CD8, and anti- $\mathrm{T}_{\mathrm{i} 3 \mathrm{~A}}$ using FITC anti-mouse Ig, analyzed by single color immunofluorescence, as well as biotin-conjugated anti-CD2, anti-CD4, and anti-CD8 stained with avidin-Texas Red, analyzed by single-color immunofluorescence.

The proportion of $\mathrm{T}_{\mathrm{izA}}+$ lymphocytes analyzed by single-color immunofluorescence was determined by using forward-angle and $90^{\circ}$ light scatter to gate on the lymphocytes. The proportion of $\mathrm{T}_{\mathrm{i} 3 \mathrm{~A}^{+}}$lymphocytes was then calculated by subtracting the control sample value from the values using anti- $T_{i 3 A}$; in all cases, the control samples incubated with isotype-matched Ig and stained with FITC-anti-mouse Ig labeled $<1 \%$ of lung and blood cells. Alternatively, to account for small variations in the amounts of lymphocytes in the different samples detected within the lymphocyte gates, the percentage of $T_{i 3 A^{+}}$ lymphocytes was also estimated by dividing the percent $T_{i 3 A^{+}}$values by the fraction of total $\mathrm{CD2}^{+} \mathrm{T}$ cells in the lymphocyte gate.

The proportion of $\mathrm{T}_{\mathrm{i} 3 \mathrm{~A}^{+}} \mathrm{CD} 2^{+}$lymphocytes analyzed by two-color immunofluorescence was determined by first gating on lymphocytes using forward-angle and $90^{\circ}$ light scatter, and evaluating the contour plots by quadrant analysis to identify unstained cells, single-stained cells, and double-stained cells as compared with control samples. The proportion of $\mathrm{T}_{\mathrm{i} 3 \mathrm{~A}^{+}} \mathrm{CD} 2^{+}$lymphocytes was directly determined by gating on the $\mathrm{CD} 2^{+}$lymphocyte population and determining the percent $\mathrm{T}_{\mathrm{i} 3 \mathrm{~A}^{+}}$lymphocytes within the $\mathrm{CD} 2^{+}$lymphocyte gate. Similarly, the proportion of $\mathrm{T}_{\mathrm{i} 3 \mathrm{~A}^{+}} \mathrm{CD4}^{+}$and $\mathrm{T}_{\mathrm{i} 3 \mathrm{~A}^{+}} \mathrm{CD8}^{+}$lymphocytes was analyzed using two-color immunofluorescence by first gating on lymphocytes using forward-angle and $90^{\circ}$ light scatter, evaluating the contour plots by quadrant analysis based on control samples, further gating on either the $\mathrm{CD}^{+}$or $\mathrm{CD}^{+}$lymphocyte population, and determining the percent $\mathrm{T}_{\mathrm{i} 3 \mathrm{~A}^{+}}$lymphocytes within the $\mathrm{CD4}^{+}$or $\mathrm{CD8} 8^{+}$lymphocyte gates. The controls included samples incubated with control-Ig, stained with FITC-anti-mouse Ig and then incubated with biotin-control-Ig, and stained with avidin-Texas Red. In all cases, the controls labeled $<1 \%$ of lung and blood cells in the lymphocyte gate chosen.

Northern and Southern blot analysis. Northern analysis was used to evaluate lung and blood $T$ lymphocyte RNA for the presence of $V_{\beta} 8$ containing $T$ cell $\beta$-chain mRNA transcripts. Using guanidine isothiocyanate (41), total cellular lymphocyte RNA was extracted from cells, size fractionated (10 $\mu \mathrm{g} / \mathrm{lane})$ on $1 \%$ agarose gels under denaturing conditions, transferred to nitrocellulose filters, and hybridized to a ${ }^{32}$ P-labeled $V_{\beta} R E X$ gene probe. $\left(V_{\beta} R E X\right.$, a 450-bp Eco RI/Hind III cDNA fragment isolated from $\mathrm{pV}_{\beta} \mathrm{REX}$ (provided by $\mathrm{E}$. Reinherz) specifically hybridizes to $\mathrm{V}_{\beta} 8$ subfamily genes [40].) $A{ }^{32} \mathrm{P}$-labeled cDNA $\beta$-chain gene $C$ region probe $C_{\beta} R E X$ (800-bp Eco $R I / B g l$ II fragment isolated from $\mathrm{pC}_{\beta} \mathrm{REX}$ [42] provided by $\mathrm{E}$. Reinherz) served as a control for possible variations in $\mathrm{T}$ cell antigen receptor $\beta$-gene expression among the different preparations. The relative amounts of hybridization with $V_{\beta} R E X$ and $C_{\beta} R E X$ were determined by comparing densitometric analysis of the resulting autoradiograms.

Southern analysis was used to evaluate lung and blood $T$ lymphocyte DNA and neutrophil DNA for the presence of possible clonal rearrangements or deletions of germline $V_{\beta} 8$ subfamily genes. DNA was recovered by standard techniques, digested $(6 \mu \mathrm{g})$ with the restriction enzymes Bam HI or Eco RI in appropriate buffers, analyzed by fractioning by size on $0.8 \%$ agarose gels, transferred to nitrocellulose 
filters (43), and hybridized to a ${ }^{32} \mathrm{P}$-labeled $\mathrm{V}_{\beta} \mathrm{REX}$ probe (specific activity $2-4 \times 10^{8} \mathrm{dpm} / \mu \mathrm{g}$ DNA). To insure that there would be hybridization to all known members of the $V_{\beta} 8$ gene subfamily, the Southern analyses were carried out using final washes with $1 \times$ SSC $\left(0.15 \mathrm{M} \mathrm{NaCl} / 0.015 \mathrm{M}\right.$ sodium citrate) plus $0.1 \% \mathrm{SDS}$ at $65^{\circ} \mathrm{C}$. To evaluate the lower limit of detection of unique $V_{\beta} 8$ gene rearrangements, mixing experiments were performed to dilute germline DNA from blood neutrophils with DNA from the Jurkat $T$ cell tumor line, a clone with a known rearrangement of a $V_{\beta} 8.1$ allele $(7,44)$. Southern analysis was carried out for DNA mixtures in which the Jurkat DNA represented $50,30,20,10,8,5,3,2$, and $1 \%$, respectively, of the total DNA content, using the conditions described above.

HLA typing. The MHC background of the patients with sarcoidosis was evaluated by determining the HLA-A, B, C, DR, and DQ types using the standard microcytotoxicity assay (45). The antisera used were capable of detecting all currently defined World Health Organization HLA and provisional workshop specificities at the HLA-A, B, C, and DR and DQ loci.

\section{Results}

Expression of $T_{i 3 A}$ surface determinants by normal and sarcoid lung and blood T lymphocytes. Evaluation of lung and blood $T$ lymphocytes from individuals with sarcoidosis with the MAb anti- $T_{i 3 A}$ demonstrated a remarkable preferential use of the $\mathrm{V}_{\beta} 8$ variable region-encoded gene elements. In this regard, whereas only a small proportion of both normal blood and lung lymphocytes were $\mathrm{T}_{\mathrm{i} 3 \mathrm{~A}^{+}}$, a strikingly increased proportion of both sarcoid blood and lung lymphocytes stained positive with this antibody (Fig. 1). Two-color indirect immunofluorescence using anti- $\mathrm{T}_{\mathrm{i} 3 \mathrm{~A}}$ and anti-CD2 confirmed that the anti$T_{i 3 A}$ positive cells in the lymphocyte gate were indeed $T$ lymphocytes (Fig. 2). In this regard, the percentage of $\mathrm{T}_{\mathrm{i3A}} \mathrm{CD}^{+}$ blood and lung lymphocytes correlated closely with the percent $\mathrm{T}_{\mathrm{i3A}}$ lymphocytes in blood and lung samples as identified by single-color immunofluorescence. Whereas the control FITC labeled antibodies and avidin-Texas Red antibodies did not identify cells in the anti- $\mathrm{T}_{\mathrm{i} 3 \mathrm{~A}^{+}} \mathrm{CD} 2^{+}$quadrant for normal

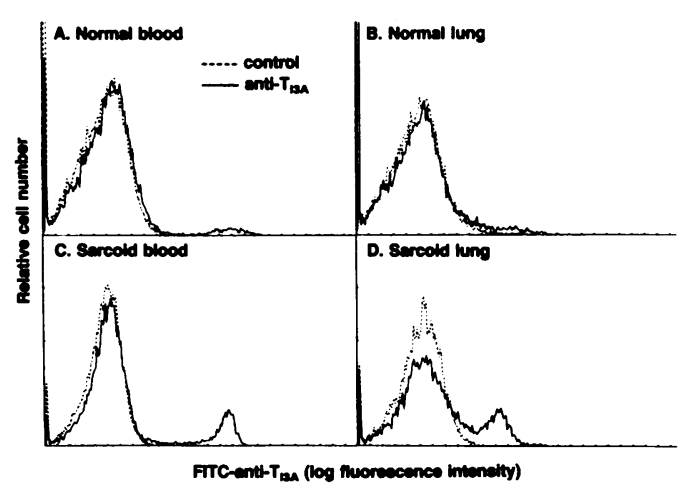

Figure 1. Expression of the $T_{\mathrm{i} 3 \mathrm{~A}}$-surface antigen on blood and lung $T$ lymphocytes of normal individuals and individuals with active sarcoidosis. Blood and lung lymphocytes were evaluated with anti- $T_{i 3 A}$ and FITC-conjugated goat anti-mouse Ig using flow cytometry (-). A nonrelevant mouse Ig with the same isotype as the anti$T_{i 3 A}$ plus FITC-conjugated goat anti-mouse Ig served as a control $(--)$. Shown is the analysis based on a lymphocyte gate determined by forward angle and $90^{\circ}$ light scatter. Ordinate, relative cell number. Abscissa, log fluorescence intensity at $488 \mathrm{~nm}$. (A) Blood lymphocytes of a normal individual. $(B)$ Lung lymphocytes of the same individual in $A$. (C) Blood lymphocytes of an individual with active pulmonary sarcoidosis. (D) Lung lymphocytes of the individual in $C$. or sarcoid blood and lung cells (Fig. 2, $A, C, E$, and $G$ ), and the normal blood $(B)$ and normal lung $(D)$ rarely contained anti$\mathrm{T}_{\mathrm{i} 3 \mathrm{~A}^{+}} \mathrm{CD} 2^{+}$cells, both sarcoid blood $(F)$ and sarcoid lung $(H)$ clearly contained cells stained with both antibodies.

Analysis of the group of normal individuals revealed that, as described by Acuto et al. (40), an average of $2 \pm 1 \%$ of normal blood lymphocytes were $\mathrm{T}_{\mathrm{i} 3 \mathrm{~A}^{+}}$(Fig. 3). Evaluation of normal lung lymphocytes demonstrated that, similar to blood, a small proportion ( $2 \pm 1, P>0.05$ compared with blood, two-tailed $t$ test) were $\mathrm{T}_{\mathrm{i} 3 \mathrm{~A}^{+}}$. In marked contrast, a significant proportion of the group of individuals with sarcoidosis showed a bias in the use of the $V_{\beta}$ 8-encoded $T_{i 3 A}$ surface determinant among both blood and/or lung lymphocytes. As a group, individuals with sarcoidosis demonstrated a striking non-Gaussian distribution of the frequency of $\mathrm{T}_{\mathrm{i} 3 \mathrm{~A}^{+}} \mathrm{T}$ lymphocytes in lung and blood $\mathrm{T}$ lymphocyte populations. In this regard, using 7\% (i.e., $3 \mathrm{SD}$ above the mean) as the highest level for the normal range of blood and lung lymphocytes, 4 of 21 (19\%) sarcoid individuals had more $\mathrm{T}_{\mathrm{i} 3 \mathrm{~A}^{+}}$blood lymphocytes than this level. Even more striking, 8 of 21 sarcoid individuals had $>7 \% \mathrm{~T}_{\mathrm{i} 3 \mathrm{~A}^{+}}$lung lymphocytes, i.e., $38 \%$ had a value $>3$ SD above the average percent $\mathrm{T}_{\mathrm{i} 3 \mathrm{~A}^{+}}$normal lung or blood lymphocytes. Similar results were found in the comparison of $\mathrm{T}_{\mathrm{i} 3 \mathrm{~A}^{+}}$lymphocytes of normal and sarcoid individuals when the percent $T_{i 3 A^{+}}$lymphocytes in blood and lung $T$ cell populations were quantified by dividing the percent of $\mathrm{T}_{\mathrm{i} 3 \mathrm{~A}}$ lymphocytes by the fraction of $\mathrm{CD} 2^{+}$lymphocytes in the lymphocyte gate (as determined by forward-angle plus $90^{\circ}$ light scattering).

Although it is possible that the bias for $\mathrm{T}_{\mathrm{i} 3 \mathrm{~A}^{+}}$lymphocytes is not sarcoid disease specific, limited data from a group of individuals with hypersensitivity pneumonitis $(n=3)$ or berylliosis $(n=3)$, two lung diseases characterized by $\mathrm{T}$ cell inflammation and granuloma formation (33-35), demonstrated no evidence for preferential accumulation of $\mathrm{T}_{\mathrm{i} 3 \mathrm{~A}^{+}}$lymphocytes. For this group, the percent $T_{i 3 A^{+}}$lymphocytes in lung averaged $2.9 \pm 1 \%$ (range 1.4 to $4.3 \%$ ) and in blood $2.6 \pm 1 \%$ (range 1.8 to $2.7 \%$ ), not significantly different from normal lung and blood $\mathrm{T}$ cell populations ( $P>0.05$, all comparisons).

Whereas there were more individuals with sarcoidosis with $>7 \% \mathrm{~T}_{\mathrm{i} 3 \mathrm{~A}^{+}}$lung lymphocytes than those with $>7 \% \mathrm{~T}_{\mathrm{i} 3 \mathrm{~A}^{+}}$blood lymphocytes, 4 of 21 of the sarcoid group had $>7 \% \mathrm{~T}_{\mathrm{i} 3 \mathrm{~A}^{+}}$ lymphocytes in both blood and lung. For these individuals, the frequency of $\mathrm{T}_{\mathrm{i} 3 \mathrm{~A}^{+}}$lymphocytes was as high or higher in the lung than their autologous blood $T$ cell populations. Consistent with these results, when all 21 individuals with sarcoidosis were analyzed, the proportion of $\mathrm{T}_{\mathrm{i} 3 \mathrm{~A}^{+}}$lymphocytes was in general higher in the lung than in the autologous blood $\mathrm{T}$ cell population ( $P<0.05$, Wilcoxon signed rank test), suggesting compartmentalization of $\mathrm{T}_{\mathrm{i} 3 \mathrm{~A}^{+}}$cells to the lung, a major site of disease in sarcoidosis.

Because it is possible the $T_{i 3 A^{+}} T$ cells observed in sarcoid may represent antigen-specific $T$ cells, the knowledge that the $T$ cell antigen receptor binds to antigen in the context of MHC proteins suggests the possibility that the selection for $\mathrm{V}_{\beta} 8$ surface epitopes may be due to common MHC proteins in this subgroup. To evaluate this concept, HLA typing was carried out on 15 of 21 individuals in the sarcoid group, including six of the eight individuals characterized by high levels of $\mathrm{T}_{\mathrm{i} 3 \mathrm{~A}^{+}}$ lymphocytes in their lung or blood (i.e., $>7 \% \mathrm{~T}_{\mathrm{i} 3 \mathrm{~A}^{+}}$lung or blood $\mathrm{T}$ lymphocytes). Except that four of six individuals in the high $\mathrm{T}_{\mathrm{i} 3 \mathrm{~A}^{+}}$subgroup were Cw3 positive (versus $0 / 9$ in the remaining sarcoid group), no dominant HLA type A, B, C, 


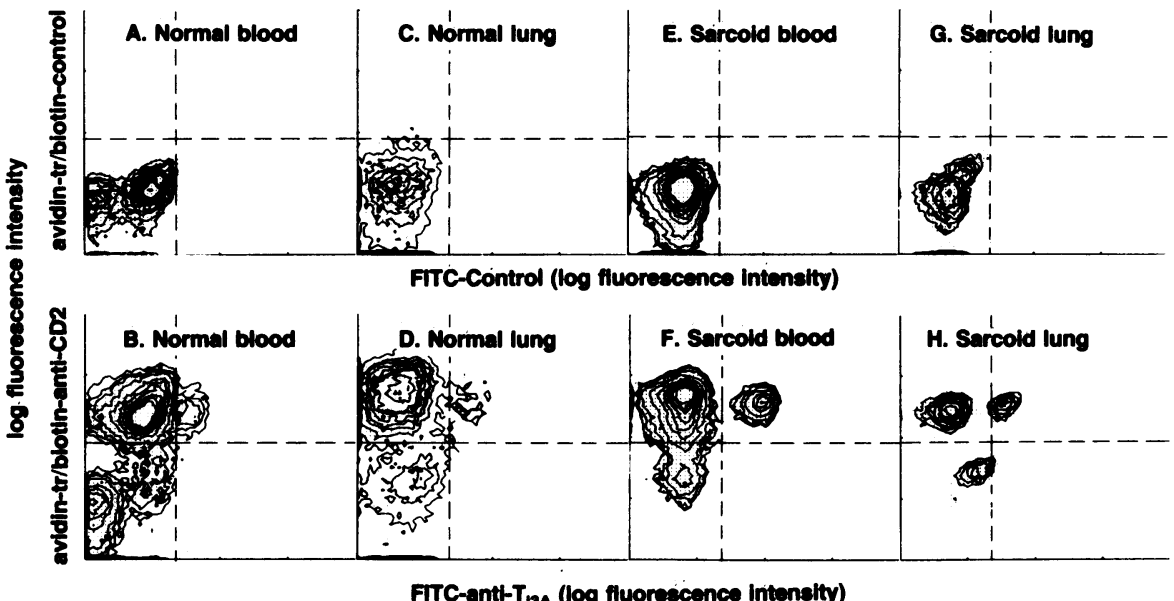

FTC-anth-T $T_{13 a}$ (log fluorescence Intensity)
Figure 2. Confirmation that the $\mathrm{T}_{\mathrm{i} 3 \mathrm{~A}}$ surface antigen-positive lymphocytes in sarcoidosis are $T$ lymphocytes. Blood and lung lymphocytes of a normal individual $(A-D)$ and an individual with active pulmonary sarcoidosis $(E-H)$ were evaluated with anti- $\mathrm{T}_{\mathrm{i} 3 \mathrm{~A}}$ (detected with FITC-antimouse Ig) and biotin anti-CD2 (T11, pan $T$ cell; detected with avidin-Texas Red [tr] conjugate) using dual-laser flow cytometry. Controls included parallel wells incubated with isotyped-matched, nonrelevant mouse myeloma antibodies stained with FITCanti-mouse Ig followed by further incubation with biotin-conjugated, nonrelevant mouse myeloma antibodies stained with avidin-tr. The gate was set on lymphocytes as determined by forward angle and $90^{\circ}$

light scatter in a fashion identical to Fig. 1. Ordinate, log fluorescence intensity (for Texas Red). Abscissa, log fluorescence intensity (for fluorescein). Contour plots were divided into quadrants based on control samples to identify unstained cells (lower left), single-stained cells (lower right, FITC-staining cells; upper left, Texas Red-staining cells), and dual fluorescence-stained cells (upper right).

$\mathrm{DR}$, or DQ was apparent in either the high $\mathrm{T}_{\mathrm{i} 3 \mathrm{~A}^{+}}$sarcoid subgroup or when all sarcoid individuals were grouped together.

$V_{\beta} 8 m R N A$ expression in sarcoid lung and blood $T$ lymphocytes. To evaluate whether lung and blood $\mathrm{T}$ lymphocyte populations that contained increased numbers of $T_{i 3 A^{+}} T$ cells were actively expressing mRNA transcripts of the $V_{\beta} 8$ gene subfamily and to confirm the relative compartmentalization of $\mathrm{T}_{\mathrm{i3A}} \mathrm{A}^{+}$lymphocytes to the lung, Northern analysis of total RNA of lung and blood lymphocytes was carried out using the cDNA probe $V_{\beta} R E X$. Consistent with the fact that $V_{\beta} R E X$ was cloned from the same tumor cell line to which the anti$T_{i 3 A}$ antibody is directed and that $V_{\beta} R E X$ has been shown to hybridize to human $V_{\beta} 8$ subfamily genes (40), RNA from individuals with sarcoidosis with $>7 \% \mathrm{~T}_{\mathrm{i} 3 \mathrm{~A}^{+}}$lymphocytes in lung clearly contained larger amounts of $\mathrm{V}_{\beta} 8^{+}$mRNA transcripts

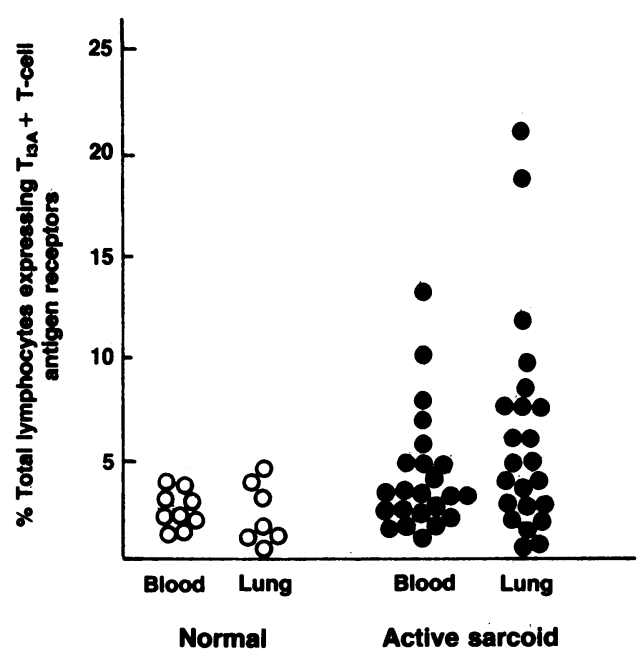

Figure 3. Expression of $T_{i 3 A}$ surface determinants on lung and blood lymphocytes of individuals with active sarcoidosis and normal individuals using single-color indirect immunofluorescence and flow cytometric analysis. Data are presented as percent of $\mathrm{T}_{\mathrm{i} 3 \mathrm{~A}^{+}}$lymphocytes for lung and blood of normal individuals $(0)$ or individuals with active sarcoidosis (๑). Quantification was by flow cytometry analysis as in Fig. 1. than autologous blood lymphocytes and blood of normals (Fig. 4). In this regard, as a control, hybridization of the ${ }^{32} \mathrm{P}$ labeled $\mathrm{V}_{\beta} \mathrm{REX}$ probe to the $\mathrm{V}_{\beta} 8$-expressing $\mathrm{T}$ cell tumor line Jurkat $(7,44)$ demonstrated a single 1.3 -kb band (Fig. 4 , lane 2). In contrast, RNA from CCRF-CEM (a $T$ cell tumor that does not express $V_{\beta} 8$ [44]) had no detectable mRNA hybridizing with the $\mathrm{V}_{\beta} \mathrm{REX}$ probe (lane 1 ). Normal blood $\mathrm{T}$ lymphocytes demonstrated faint, but detectable, single mRNA transcripts hybridizing to $\mathrm{V}_{\beta} \mathrm{REX}$ (lane 3), similar to prior reports (40). Importantly, consistent with results using anti- $T_{i 3 A}$ surface staining, individuals with sarcoidosis who had increased numbers of $\mathrm{T}_{\mathrm{i} 3 \mathrm{~A}^{+}} \mathrm{T}$ cells in their lung demonstrated increased amounts of $\mathrm{V}_{\beta} \mathrm{REX}^{+}$mRNA transcripts in RNA from lung compared to autologous blood $\mathrm{T}$ cells (lanes 4-7). Evaluation of these same samples demonstrated the expression of similar amounts of $\mathrm{C}_{\beta} \mathrm{REX}^{+}$mRNA indicating the differences in $\mathrm{V}_{\beta} 8$ gene expression were not due to variations in $\mathrm{T}$ cell antigen receptor $\beta$-chain mRNA expression.

Expression of $T_{i 3 A}$ surface determinants in sarcoid $T$ cell subsets. With the knowledge that sarcoidosis is characterized by the accumulation of $\mathrm{CD}^{+}$lymphocytes at sites of disease such as the lung (21-31), and that the $T_{i 3 A}$ epitope has been shown to be used without preference in both $\mathrm{CD}^{+}$and $\mathrm{CD} 8^{+}$ normal blood $T$ cells (40), blood and lung lymphocytes of individuals with sarcoidosis were evaluated for the expression of the $T_{i 3 A}$ epitope in these subsets. Interestingly, the $T_{i 3 A}$ epitope was expressed across CD4 and CD8 phenotypes in blood and lung lymphocytes of individuals with sarcoidosis as it is in normal individuals (Fig. 5). Significantly, the ratio of $\mathrm{T}_{\mathrm{i3A}}$ $\mathrm{CD}^{+}$to $\mathrm{T}_{\mathrm{i} 3 \mathrm{~A}^{+}} \mathrm{CD} 8^{+}$lymphocytes in the sarcoid lung was markedly elevated (compare $C$ with $D$ ), whereas it was reversed in the blood (compare $A$ with $B$ ). However, the $\mathrm{T}_{\mathrm{i} 3 \mathrm{~A}^{+}}$ $\mathrm{CD}^{+}$to $\mathrm{T}_{\mathrm{i3A}} \mathrm{CD}^{+}$ratio in the two compartments in the sarcoid patients approximated the overall $\mathrm{CD}^{+} / \mathrm{CD}^{+}$lymphocyte ratios in lung and blood, i.e., the compartmentalization of the $\mathrm{T}_{\mathrm{i} 3 \mathrm{~A}^{+}}$cells tracked with the compartmentalization of $\mathrm{CD}^{+}$and $\mathrm{CD} 8^{+}$lymphocytes in lung and blood in active pulmonary sarcoidosis. The net result of this compartmentalization was a striking dominance of $\mathrm{CD}^{+}{ }^{+} \mathrm{T}_{\mathrm{i} 3 \mathrm{~A}^{+}}$lymphocytes in the lung with a sharply contrasting dominance of $\mathrm{CD8}^{+} \mathrm{T}_{\mathrm{i3A}} \mathrm{A}^{+}$ lymphocytes in the blood. These observations suggest that, in a 


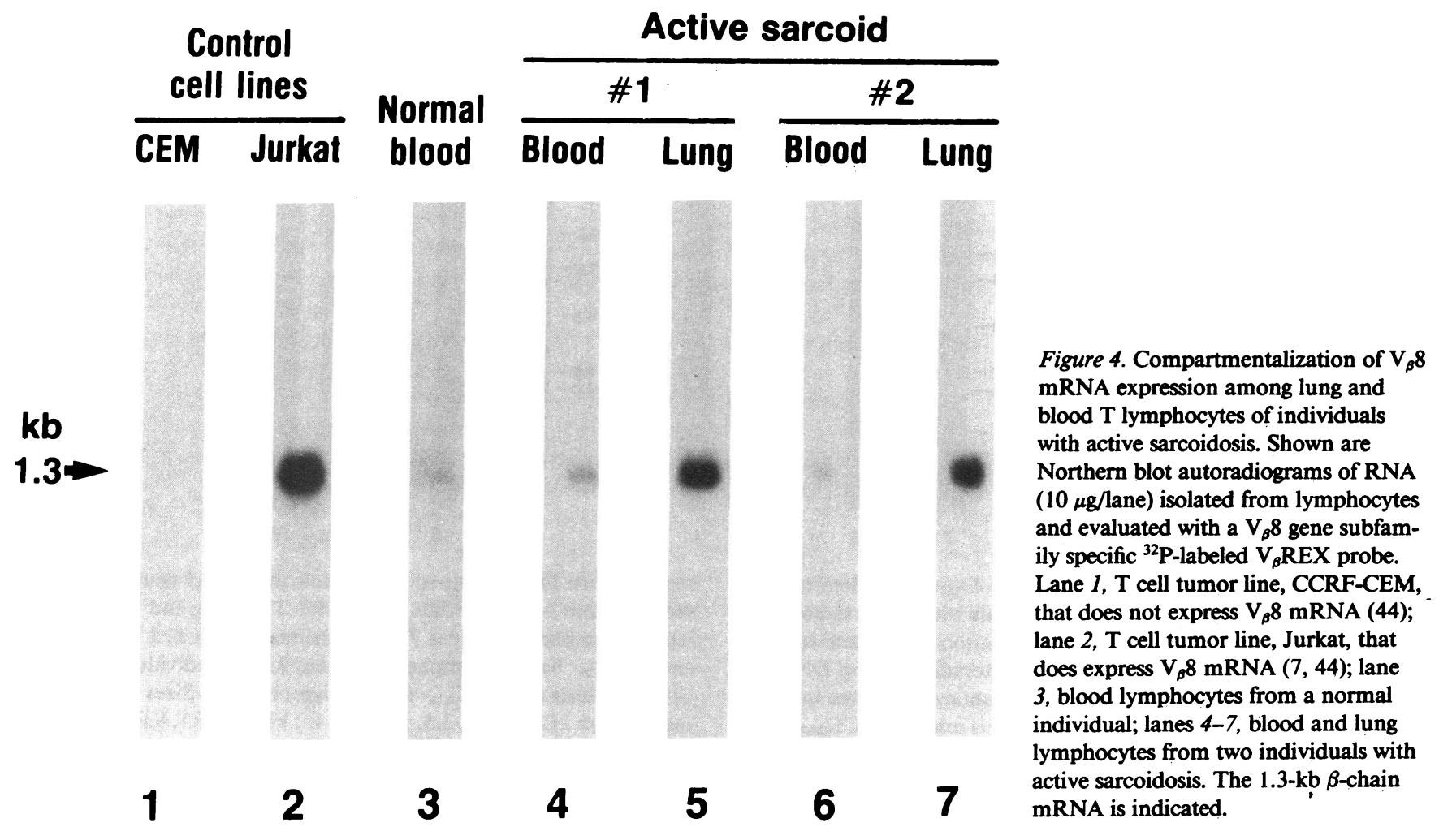

Figure 4. Compartmentalization of $\mathrm{V}_{\beta} 8$ Tymphocytes of individual Northern blot autoradiograms of RNA (10 $\mu \mathrm{g} /$ lane) isolated from lymphocytes and evaluated with a $V_{\beta} 8$ gene subfamily specific ${ }^{32} \mathrm{P}$-labeled $\mathrm{V}_{\beta} R E X$ probe. Lane $1, \mathrm{~T}$ cell tumor line, CCRF-CEM, that does not express $V_{\beta} 8$ mRNA (44); lane 2 , $T$ cell tumor line, Jurkat, that does express $\mathrm{V}_{\beta} 8 \mathrm{mRNA}(7,44)$; lane 3 , blood lymphocytes from a normal individual; lanes 4-7, blood and lung lymphocytes from two individuals with mRNA is indicated.

subgroup of individuals with this disease, the $T$ cells expressing the single idiotope defined by anti- $\mathrm{T}_{\mathrm{i} 3 \mathrm{~A}}$ contribute substantially to the overall accumulation of $\mathrm{CD}^{+}$lymphocytes at the site of disease.

Absence of clonal populations of $T$ cell receptor antigen $V_{\beta} 8^{+}$gene rearrangements in sarcoid lung and blood $T$ cell populations. Given the presence of increased numbers of $\mathrm{T}_{\mathrm{i3A}} \mathrm{A}^{+}$ lymphocytes that express $\mathrm{V}_{\beta} 8$ subfamily genes in sarcoid lung and blood $T$ cell populations, the possibility exists that a significant proportion of the $\mathrm{T}_{\mathrm{i} 3 \mathrm{~A}^{+}}$lymphocytes represented expansions of one, or very few, dominant clones. If so, these $T_{i 3 A^{+}} T$ cell clones would be characterized by identical $T$ cell antigen receptor $\beta$-gene rearrangements. Alternatively, the expanded numbers of $T_{i 3 A^{+}} T$ lymphocytes may reflect selection for $V_{\beta} 8$ determinants without regard to a specific $V_{\beta} 8$ subfamily member or to $\mathrm{D}_{\beta}, \mathrm{J}_{\beta}$, or $\mathrm{C}_{\beta}$ determinants. To differentiate among these possibilities, Southern blot analysis was performed on DNA obtained from sarcoid lung and blood $T$ cell populations using a $\mathrm{V}_{\beta} 8$-specific gene probe, using germline (unrearranged) DNA from blood neutrophils of these individuals for comparison (Fig. 6). When digested with Bam HI or Eco RI, neutrophil DNA of sarcoid patients in all cases demonstrated five members of the $V_{\beta} 8$ subfamily $(7,46)$ suggesting no germline deletions of $V_{\beta} 8$ subfamily gene members in this disorder (Fig. 6, lanes 1, 4, 7, 10, 13, and 16). The absence of a 2.0-kb fragment with Bam $\mathrm{HI}$ digestion in patient 2 is the result of a homozygous polymorphism of $V_{\beta} 8.1$ alleles resulting in 23-kb size fragments (Fig. 6, lane 7) (47). Using Eco RI, an additional faint, but discernable, sixth band was seen in most DNA samples, possibly representing a distantly related variable-region gene segment of lower homology than the defined five members of the $V_{\beta} 8$ subfamily. Interestingly, despite the expanded numbers of $T_{i 3 A^{+}} T$ lymphocytes in sarcoid lung

and blood, DNA from these $T$ cell populations showed no clonal rearrangements or deletions by this analysis (lanes 2,3 , $5,6,8,9,11,12,14,15,17$, and 18). The sensitivity of this

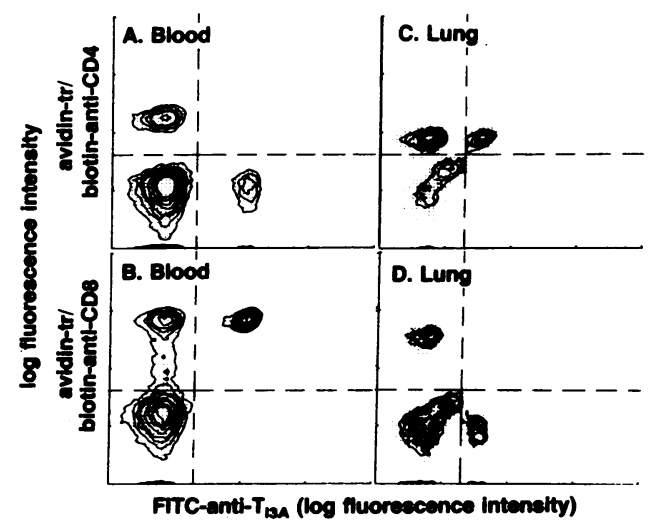

Figure 5. Compartmentalization of $\mathrm{T}_{\mathrm{i3A^{+ }}} \mathrm{CD}^{+}$and $\mathrm{T}_{\mathrm{i} 3 \mathrm{~A}^{+}} \mathrm{CD8} 8^{+}$subsets of lung and blood lymphocytes of individuals with active sarcoidosis. Blood $(A$ and $B)$ and lung $(C$ and $D) \mathrm{T}$ lymphocytes were evaluated with anti- $\mathrm{T}_{\mathrm{i} 3 \mathrm{~A}}$ (detected with FITC-anti-mouse Ig) and either biotin-anti-CD4 (detected with avidin-Texas-Red [tr]; $A$ and $C$ ) or biotin-anti-CD8 (detected with avidin-tr; $B$ and $D$ ), using duallaser flow cytometry. Controls included parallel wells incubated with isotyped-matched, nonrelevant mouse myeloma antibodies stained with FITC-anti-mouse Ig followed by further incubation with biotinconjugated, nonrelevant mouse myeloma antibodies stained with avidin-tr, as outlined in Methods. The gate was set on lymphocytes as determined by forward-angle and $90^{\circ}$ light scatter. Ordinate, log fluorescence intensity (for Texas Red). Abscissa, log fluorescence intensity (for fluorescein). Contour plots were divided into quadrants based on control samples to identify unstained cells (lower left), single-stained cells (lower right, FITC-staining cells; upper left, Texas Red-staining cells), and dual fluorescence-stained cells (upper right). 


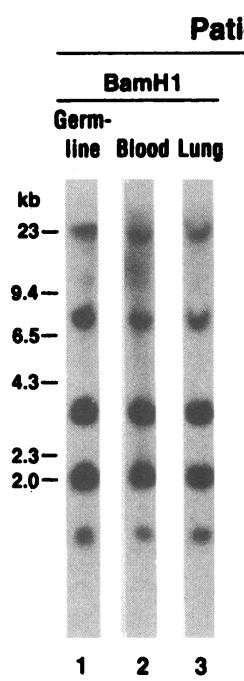

Patient \#1

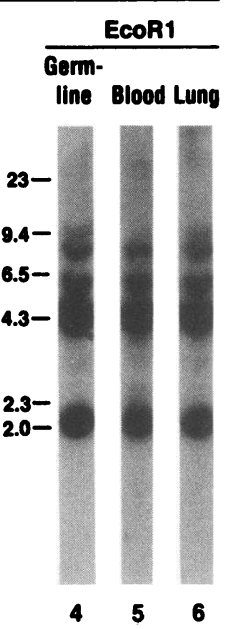

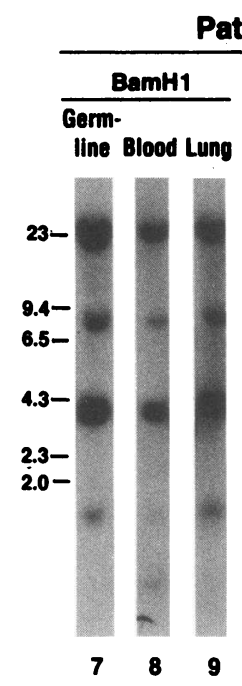

Patient \#2

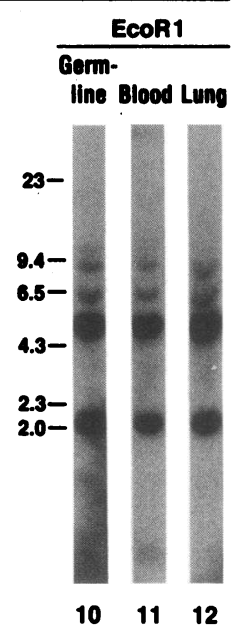

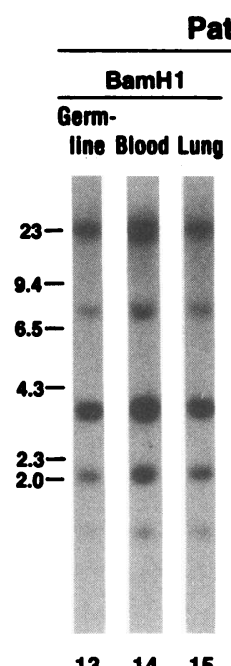

$\begin{array}{lll}13 & 14 & 15\end{array}$
Patient \#3

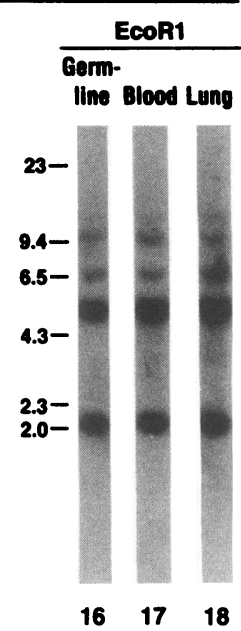

Figure 6. Evidence that the biased use of the $\mathrm{T}_{\mathrm{i} 3 \mathrm{~A}}$-surface determinant of the $V_{\beta} 8$ subfamily genes in individuals with active sarcoidosis occurs in an apparent clonally diverse population of lung and blood T lymphocytes. Shown are Southern blot autoradiograms of DNA (6 $\mu \mathrm{g} /$ /ane) extracted from lung and blood lymphocytes of three individuals with active sarcoidosis who had increased numbers of $T_{i 3 A^{+}}$lymphocytes in their lung or blood $\mathrm{T}$ cell populations compared with normal individuals. DNA was digested with Bam H1 or Eco R1 and hybridized with a ${ }^{32} \mathrm{P}$-labeled $\mathrm{V}_{\beta} 8$ gene probe $\left(\mathrm{V}_{\beta} R E X\right)$. For compari-

Southern blot analysis for detecting monoclonal $\mathrm{V}_{\beta} 8$ rearrangements was assessed by mixing experiments using $V_{\beta} 8$ rearranged DNA from a Jurkat $T$ cell line and unrearranged germline DNA. These experiments demonstrated that $V_{\beta} 8$ rearranged $\mathrm{T}$ cell DNA could be detected when it made up $5-8 \%$ of the total DNA mixture (not shown). Since the Jurkat $T$ cell line has only one rearranged $V_{\beta} 8$ allele, these results indicate the Southern analysis experiments were capable of detecting a monoclonal $T_{i 3 A^{+}} T$ cell population (with only a single $V_{\beta} 8$ gene rearrangement) representing $5-8 \%$ of a $T$ cell population. The lack of evidence of clonal rearrangements of $\mathrm{V}_{\beta} 8$ genes by Southern analysis of sarcoid lung and blood DNA thus excludes a monoclonal origin of all $\mathrm{T}_{\mathrm{i3A^{+ }}} \mathrm{T}$ cells in sarcoid lung and blood lymphocyte populations with elevated proportions of $\mathrm{T}_{\mathrm{i} 3 \mathrm{~A}^{+}}$lymphocytes. Further, in sarcoid $\mathrm{T}$ cell populations with $10-21 \% \mathrm{~T}_{\mathrm{i3A}} \mathrm{A}^{+} \mathrm{T}$ cells, the lack of clonal $\mathrm{V}_{\beta} 8$ gene rearrangements suggests that several $\mathrm{V}_{\beta} 8^{+} T$ cell clones are likely responsible for the increase in $\mathrm{T}_{\mathrm{i3} \mathrm{A}^{+}}$lymphocytes observed. These $T_{i 3 A^{+}} T$ cells may use more than one member of the $V_{\beta} 8$ gene subfamily or different $\beta$-gene locus $D_{\beta}, J_{\beta}$, and $\mathrm{C}_{\beta}$ combinations. However, these studies do not define an upper limit for the number of unique $\mathrm{V}_{\beta} 8^{+} \mathrm{T}$ cell clones and thus it is plausible that a small number of $\mathrm{V}_{\beta} 8^{+} \mathrm{T}$ cell clones is responsible for the increase in $\mathrm{T}_{\mathrm{i} 3 \mathrm{~A}^{+}}$lymphocytes in sarcoid lung and blood.

\section{Discussion}

Sarcoidosis is a chronic disorder characterized in affected organs by the accumulation of activated, helper/inducer $\left(\mathrm{CD4}^{+}\right) \mathrm{T}$ lymphocytes (21-31). Using a clonotypic MAb directed against an idiotope on the $\beta$-chain of the $T$ cell antigen receptor coded by the $\mathrm{V}_{\beta} 8$ subfamily genes, this study presents evidence that a subgroup of individuals with active pulmonary son, germline DNA obtained from autologous blood neutrophils is shown. Lanes 1-6, individual 1 with $19 \% \mathrm{~T}_{\mathrm{i} 3 \mathrm{~A}^{+}}$lung and $13 \% \mathrm{~T}_{\mathrm{i3A}} \mathrm{A}^{+}$ blood $\mathrm{T}$ lymphocytes; lanes $7-12$, individual 2 with $11 \% \mathrm{~T}_{\mathrm{i} 3 \mathrm{~A}^{+}}$lung and $3 \% \mathrm{~T}_{\mathrm{i} 3 \mathrm{~A}^{+}}$blood $\mathrm{T}$ lymphocytes; lanes $13-18$, individual 3 with $21 \% \mathrm{~T}_{\mathrm{i} 3 \mathrm{~A}^{+}}$lung and $2 \% \mathrm{~T}_{\mathrm{i3A}}$ blood $\mathrm{T}$ lymphocytes. Sizes of the fragments (Bam Hl, 23, 7.0, 3.5, 2.0, and 1.2 kb; Eco R1, 9.0, 6.0, 4.6, 4.4 , and $2.0 \mathrm{~kb}$ plus a faint $9.6-\mathrm{kb}$ fragment seen in most samples) were determined using conventional markers.

sarcoidosis is characterized in lung, and to a lesser degree in blood, by expanded proportions of $T$ cells with antigen receptors expressing this idiotope. Furthermore, this subgroup of individuals demonstrates a striking compartmentalization of these $\mathrm{V}_{\beta} 8^{+} \mathrm{T}$ cells, with the $\mathrm{V}_{\beta} 8^{+} \mathrm{T}$ cells on the pulmonary epithelial surface dominated by $\mathrm{T}$ cells of the helper/inducer $\left(\mathrm{CD}^{+}\right)$phenotype, and with blood $\mathrm{T}$ cells dominated by those of the suppressor/cytotoxic $\left(\mathrm{CD}^{+}\right)$phenotype. Put in the context that normal individuals do not show such biases among $T$ cells in blood or lung, these observations suggest that sarcoidosis is associated with a major perturbation in the usage of the $\mathrm{T}$ cell antigen receptor gene repertoire.

Normal usage of $V_{\beta} 8$ genes. To date, the available evidence suggests that the steady state of the immune system in normal individuals is characterized by a broad usage of a large number of $V_{\beta}$ gene segments in the rearranged genes that define the $T$ cell antigen receptor $\beta$-chains expressed in blood $T$ cells $(40$, 48-50). For example, of the $V_{\beta}$ gene segments isolated from human peripheral blood lymphocyte cDNA libraries, 22 of 27 $(81 \%)$ were different from each other in one study (48), whereas another study demonstrated that 17 of $19(89 \%)$ were dissimilar (49). For $V_{\beta} 8$ usage assessed with the anti- $T_{i 3 A}$ antibody, the proportion of normal blood $T$ cells expressing $V_{\beta} 8$ gene segments is small, and exhibits a relatively small range (40). Consistent with this concept, in addition to confirming the low level of $\mathrm{T}_{\mathrm{i3A}}+\mathrm{T}$ cells in normal blood $\mathrm{T}$ cell populations, this study demonstrates that there is a similar low-level usage with a relatively small range of $V_{\beta} 8$ gene segments among $T$ cells on the epithelial surface compartment of the normal lung. Thus, at least in normal circumstances, even on a surface of the body that is constantly exposed to environmental antigens, the steady-state diversification of usage of at least one group of $\mathrm{T}$ cell antigen receptor variable region gene segments is maintained. 
Biased usage of the $V_{\beta}$ gene repertoire in sarcoidosis. In the context of the normal, apparently unbiased, usage of $V_{\beta} 8$-encoded gene segments in normal lung and blood, the finding that a subgroup of individuals with sarcoidosis have a marked accumulation of $\mathrm{T}_{\mathrm{i} 3 \mathrm{~A}^{+}} \mathrm{T}$ cells in lung, and to a lesser extent in blood, is a striking observation that leads to several hypotheses concerning the pathogenesis of this disorder.

First, although there is no direct evidence that $\mathrm{T}_{\mathrm{i3 \textrm {A } ^ { + }}} \mathrm{T}$ cells play a central role in the pathogenesis of sarcoidosis, the observation that $\mathrm{T}_{\mathrm{i} 3 \mathrm{~A}^{+}} \mathrm{T}$ lymphocytes from the lung are predominantly $\mathrm{CD}^{+} \mathrm{T}$-helper/inducer lymphocytes is consistent with the concept that the $\mathrm{T}_{\mathrm{i3A}} \mathrm{A}^{+}$cells contribute, at least in part, to the marked accumulation of $\mathrm{CD}^{+} \mathrm{T}$ lymphocytes at sites of disease. Along with previous observations that lung $\mathrm{CD}^{+} \mathrm{T}$ cells in sarcoidosis release IL 2 (29), these observations are consistent with the concept that the accumulated $C D 4^{+} \mathrm{T}_{\mathrm{izA}} \mathrm{A}^{+}$ $T$ cells may play a central role in the enhanced immune processes at sites of disease, at least for a subgroup of sarcoid individuals. The possibility that the accumulation of $\mathrm{V}_{\beta} 8^{+} \mathrm{T}$ cells is specific for sarcoidosis is supported by limited data of other granulomatous lung diseases that, to date, have shown no evidence for $a V_{\beta} 8$ biased $T$ cell repertoire, although more extensive studies will be necessary to substantiate this as a general finding. In this context, it is conceivable that the $\mathrm{CD}^{+}$ $\mathrm{T}_{\mathrm{i3 \textrm {A } ^ { + }}} \mathrm{T}$ cells accumulate in the lung, at least in part, due to a nonspecific recruitment of $\mathrm{T}_{\mathrm{i3A}} \mathrm{A}^{+} \mathrm{T}$ cells in an inflammatory focus. For example, $V_{\beta} 8$ genes may have properties that predispose to their frequent usage in primitive immune processes that are not related to the normal use of variable region products in the usual context of $\mathrm{T}$ cell antigen receptor specificity. Consistent with this concept, mutation frequency analysis suggests that $\mathrm{V}_{\beta}$ 8 gene elements are evolving slowly, similar to most eukaryotic genes, and in marked contrast to variable region segments of immunoglobulin $V_{H}$ genes (46). In this regard, selective pressure may be acting to maintain $V_{\beta} 8$ genes for use in fundamental immunologic processes such as granuloma formation.

Second, the compartmentalization of $\mathrm{T}_{\mathrm{i3A^{+ }}} \mathrm{T}$ cells of the $\mathrm{CD}^{+}$and $\mathrm{CD}^{+}$phenotypes to the lung and blood, respectively, suggests that an active selection process, as yet undefined, is responsible for the initiation and maintenance of these apparent $T$ cell gradients. Several mechanisms, not necessarily exclusive of one another, may be responsible for this perturbation of the normal steady state. The fact that there is exaggerated proliferation of $T$ cells in the sarcoid lung $(23,26,28)$, together with activated $\mathrm{CD}^{+}$lung $\mathrm{T}$ cells in the same location $(21,29,51,52)$, is consistent with the concept that $C D 4^{+} T_{i 3 \mathrm{~A}^{+}}$ $\mathrm{T}$ cells compartmentalize to the lung secondary to selective local activation and proliferation. It is also possible that $\mathrm{CD8}^{+}$ $\mathrm{T}_{\mathrm{i3A^{+ }}}{ }^{+} \mathrm{T}$ cells also proliferate in the lung, but while the $\mathrm{CD4} 4^{+}$ population remains in the local milieu, the $\mathrm{CD}^{+} \mathrm{T}$ cells traffic to blood. Alternatively, the accumulation of $\mathrm{CD}^{+} \mathrm{T}_{\mathrm{i3A}} \mathrm{A}^{+} \mathrm{T}$ cells in the lung may result from the active recruitment and/or homing of $\mathrm{CD}^{+} \mathrm{T}_{\mathrm{i3A}}+\mathrm{T}$ cells from blood.

Third, the preferential use of a specific $V_{\beta}$ gene subfamily in a subgroup of individuals with sarcoidosis could be on an inherited basis. Consistent with this concept, sarcoidosis clearly has a familial basis, at least in some individuals (53). Furthermore, the exaggerated $\mathrm{T}$ cell proliferation, lymphadenopathy, and preferential use of a variable region segment in a clonally diverse fashion in sarcoidosis has interesting parallels to the MRL/Mp-lpr/lpr autoimmune mouse, in which the au- tosomal recessive $\mathrm{lpr}$ gene is responsible for these abnormalities in genetically predisposed mice (18). It thus is conceivable that a predisposition to sarcoidosis could be associated with a bias toward $\mathrm{V}_{\beta} 8$ gene segments, for example, secondary to polymorphisms in the $\mathrm{T}$ cell receptor $\beta$-gene locus (resulting in nonrandom $T$ cell rearrangement processes) or from polymorphisms in gene segments controlling thymic processes that normally delete self-MHC reactive $\mathrm{T}$ cells and select for antigen-specific, self-MHC restricted T cells.

Fourth, although sarcoidosis has many clinical similarities with $\mathrm{T}$ cell leukemia/lymphoma due to human $\mathrm{T}$ lymphoblastic virus (HTLV-1) retrovirus (54) and could conceivably be caused by retroviral $\mathrm{T}$ cell infection, the preferential use of $\mathrm{V}_{\beta} 8$-encoded $\mathrm{T}$ cell receptors in a significant number of sarcoid individuals in the absence of clonal rearrangements of $\mathrm{V}_{\beta}$ 8-genes argues strongly against the possibility that sarcoidosis is associated with the emergence of a random, transformed sarcoid $\mathrm{T}$ cell clone of this single $\mathrm{T}$ cell receptor clonotype.

Fifth, because the natural ligand of the $\mathrm{T}$ cell receptor is an antigen associated with class I or II MHC proteins, the bias for $\mathrm{T}_{\mathrm{i3A^{+ }}} \mathrm{T}$ cells in this subgroup of individuals with sarcoidosis may be due to selection for $\mathrm{V}_{\beta} 8$-encoded $\mathrm{T}$ cell receptors by a specific sarcoid antigen, MHC protein or antigen-MHC combination. Although the limited evaluation of MHC loci in this study argues against a dominance of specific class I or II MHC molecules being associated with the bias toward $V_{\beta} 8$ gene segment usage in sarcoidosis, this does not necessarily exclude the "specific sarcoid MHC or antigen-MHC" hypothesis. In this regard, there are examples of bias toward T cell receptor $\beta$ chain usage correlating with MHC background $(4,10,14,55)$. It thus is conceivable that in sarcoidosis, specific $\mathrm{V}_{\beta}$-expressing $T$ cells are selected by regions of MHC proteins not recognized as MHC subtypes, by nonpolymorphic regions of MHC proteins, by minor histocompatibility antigens, or by modified self-MHC proteins, either alone or in the context of a specific antigen. Furthermore, because a $\mathrm{T}$ cell receptor may have a dual affinity for an antigen plus self-MHC ligand and a foreign (allo-) MHC protein (56), this hypothesis is consistent with the finding that biases in $\mathrm{V}_{\beta}$-gene repertoire have been observed in allo-MHC reactive $T$ cell populations (13). Alternatively, the bias for $\mathrm{V}_{\beta} 8$-encoded $\mathrm{T}$ cell receptor usage in a subgroup of sarcoid patients could result from $T$ cell antigen receptor selection by a specific sarcoid antigen without regard to the MHC background at all. In this context, highly multivalent polymers of fluorescein-5-isothiocyanate can bind directly to $T$ cell antigen receptor $\alpha / \beta$ heterodimers in the absence of specific MHC recognition, suggesting the possibility that certain highly multivalent antigens alone may bind and select for specific $T$ cell receptors (57). If this occurs in sarcoidosis, the observation that preferential use of $\mathrm{V}_{\beta} 8$-expressing $\mathrm{T}$ cells was found only in a subgroup of individuals with sarcoidosis suggests that sarcoidosis likely is not due to a single sarcoid antigen, but by a variety of highly multivalent antigens, all capable of eliciting sarcoid-type granulomas. In either case, the possibility that the accumulation of $\mathrm{T}_{\mathrm{i} 3 \mathrm{~A}^{+}} \mathrm{T}$ cells in sarcoidosis represents infiltration of a limited number of unique $T$ cell clones suggests that these $T_{i 3 A^{+}} T$ cells may represent potentially important probes with which to further investigate the pathogenesis of sarcoidosis.

Lastly, the possibility exists that the bias for $T_{i 3 A^{+}} T$ cells in this sarcoid subgroup may be due to regulation of $\mathrm{V}_{\beta} 8$-encoded $T$ cell idiotypes in an antigen-independent process associated 
with idiotypic network interactions, perhaps involving both $\mathrm{CD}^{+}$and $\mathrm{CD}^{+} \mathrm{T}$ cells. This concept is supported by the lack of clonal rearrangements of $\mathrm{V}_{\beta} 8$ genes in the sarcoid subgroup, which suggests that the selection process may be based primarily for $\mathrm{V}_{\beta} 8$-encoded surface determinants. This possibility is enhanced by the knowledge that identical $V_{\beta}$ regions can occur in the construction of $T$ cell specificities to different antigen-MHC combinations (58-63). In the context of this hypothesis, the lack of expanded numbers of $\mathrm{T}_{\mathrm{i} 3 \mathrm{~A}^{+}} \mathrm{T}$ cells in all sarcoid patients may reflect heterogeneity in the etiology and/ or pathogenic mechanisms of sarcoidosis. In this case, further characterization of $\mathrm{T}$ cell receptor repertoires in sarcoidosis may demonstrate the preferential use of other variable region segments.

\section{Acknowledgments}

We thank E. Reinherz for providing anti- $T_{i 3 A} M A b$ and $p V_{\beta} R E X$ and $\mathrm{pC}_{\beta} \mathrm{REX}$ plasmid DNA; A. Boylston for providing 42-1C1 MAb; and Stephen Ip for providing A2, S5, and D6 MAb.

\section{References}

1. Meuer, S. C., K. A. Fitzgerald, R. E. Hussey, J. C. Hodgdon, S. F. Schlossman, and E. L. Reinherz. 1983. Clonotypic structures involved in antigen-specific human $\mathrm{T}$ cell function: relationship to the T3 molecular complex. J. Exp. Med. 157:705-719.

2. Yagüe, J., J. White, C. Coleclough, J. Kappler, E. Palmer, and P. Marrack. 1985. The T cell receptor: the $\alpha$ and $\beta$ chains define idiotype, and antigen and MHC specificity. Cell. 42:81-87.

3. Dembić, Z., W. Haas, S. Weiss, J. McCubrey, H. Kiefer, H. von Boehmer, and M. Steinmetz. 1986. Transfer of specificity by murine $\alpha$ and $\beta$ T-cell receptor genes. Nature (Lond.). 320:232-238.

4. Saito T., and R. N. Germain. 1987. Predictable acquisition of a new MHC recognition specificity following expression of a transfected T-cell receptor $\beta$-chain gene. Nature (Lond.). 329:256-269.

5. Hedrick, S. M., D. I. Cohen, E. A. Nielsen, and M. M. Davis. 1984. Isolation of cDNA clones encoding $T$ cell-specific membraneassociated proteins. Nature (Lond.). 308:149-153.

6. Yanagi, Y., Y. Yoshikai, K. Leggett, S. P. Clark, I. Aleksander, and T. W. Mak. 1984. A human T cell-specific cDNA clone encodes a protein having extensive homology to immunoglobulin chains. Nature (Lond.). 308:145-148.

7. Siu, G., S. P. Clark, Y. Yoshikai, M. Malissen, Y. Yanagi, E. Strauss, and T. W. Mak. 1984. The human T cell antigen receptor is encoded by variable, diversity, and joining gene segments that rearrange to generate a complete V gene. Cell. 37:393-401.

8. Concannon, P., E. Lai, M. Klein, S. Siu, E. Strauss, L. Pickering, P. Kung, R. Gatti, and L. Hood. 1986. Human T-cell receptor genes: organization, diversity, and polymorphism. Cold Spring Harbor Symp. Quant. Biol. 51:785-795.

9. Kimura, N., Toyonaga, B., Toshikai, U., R.-P. Du, and T. W. Mak. 1987. Sequences and repertoire of the human $T$ cell receptor $a$ and $\beta$ chain variable region genes in thymocytes. Eur. J. Immunol. 17:375-383.

10. Fink, P. J., L. A. Matis, D. L. McElligott, M. Bookman, and S. M. Hedrick. 1986. Correlations between T-cell specificity and the structure of the antigen receptor. Nature (Lond.). 321:219-226.

11. Winoto, A., J. L. Urban, N. C. Lan, J. Goverman, L. Hood, and D. Hansburg. 1986. Predominant use of a $V_{\alpha}$ gene segment in mouse T-cell receptors for cytochrome c. Nature (Lond.). 324:679-682.

12. Hochgeschwender, U., H.-G. Simon, H. U. Weltzien, F. Bartels, A. Becker, and J. T. Epplen. 1987. Dominance of one T-cell receptor in the H-2K ${ }^{b} / T N P$ response. Nature (Lond.). 326:307-309.

13. Garman, R. D., J.-L. Ko, C. D. Vulpe, and D. H. Raulet. 1986.
T-cell receptor variable region gene usage in T-cell populations. Proc. Natl. Acad. Sci. USA. 83:3987-3991.

14. Morel, P. A., A. M. Livingstone, and C. G. Fathman. 1987. Correlation of $\mathrm{T}$ cell receptor $\mathrm{V}_{\beta}$ gene family with MHC restriction. $J$. Exp. Med. 166:583-588.

15. Pardoll, D. M., B. J. Fowlkes, R. I. Lechler, R. N. Germain, and R. H. Schwartz. 1987. Early genetic events in T cell development analyzed by in situ hybridization. J. Exp. Med. 165:1624-1638.

16. Budd, R. C., G. C. Miescher, R. C. Howe, R. K. Lees, C. Bron, and H. R. MacDonald. 1987. Developmentally regulated expression of $T$ cell receptor $\beta$ chain variable domains in immature thymocytes. $J$. Exp. Med. 166:577-582.

17. Fowlkes, B. J., A. M. Kruisbeek, H. Ton-That, M. A. Weston, J. E. Coligan, R. H. Schwartz, and D. M. Pardoll. 1987. A novel population of T-cell receptor $\alpha \beta$-bearing thymocytes which predominantly express a single $\mathrm{V}_{\beta}$ gene family. Nature (Lond.). 329:251-254.

18. Singer, P. A., R. J. McEvilly, D. J. Noonan, F. J. Dixon, and A. N. Theofilopoulos. 1986. Clonal diversity and T-cell receptor $\beta$ chain variable gene expression in enlarged lymph nodes of MRL-lpr/ lpr lupus mice. Proc. Natl. Acad. Sci. USA. 83:7018-7022.

19. MacDonald, H. R., R. K. Lees, C. Bron, B. Sordat, and G. Miescher. 1987. T cell antigen receptor expression in athymic (nu/nu) mice: evidence for an oligoclonal $\beta$ chain repertoire. J. Exp. Med. 166:195-209.

20. Jerne, N. K. 1971. The somatic generation of immune recognition. Eur. J. Immunol. 1:1-9.

21. Crystal, R. G., W. C. Roberts, G. W. Hunninghake, J. E. Gadek, J. D. Fulmer, and B. R. Line. 1986. Pulmonary sarcoidosis: a disease characterized and perpetuated by activated lung T-lymphocytes. Ann. Intern Med. 94:73-94.

22. Hunninghake, G. W., and R. G. Crystal. 1981. Pulmonary sarcoidosis: a disorder mediated by excess helper T-lymphocyte activity at sites of disease activity. $N$. Engl. J. Med. 305:429-434.

22. Daniele, R. P., J. H. Dauber, and M. D. Rossman. 1980. Immunologic abnormalities in sarcoidosis. Ann. Intern. Med. 92:406-416.

23. Pinkston, P., P. B. Bitterman, and R. G. Crystal. 1983. Spontaneous release of interleukin- 2 by lung $T$ lymphocytes in active pulmonary sarcoidosis. $N$. Engl. J. Med. 308:793-800.

25. Modlin, R. L., F. M. Hofman, P. R. Meyer, O. P. Sharma, C. R. Taylor, and T. H. Rea. 1983. In situ demonstration of T-lymphocytes subsets in granulomatous inflammation: leprosy, rhinoscleroma and sarcoidosis. Clin. Exp. Immunol. 51:430-438.

26. Hunnnighake, G. W., G. N. Bedell, D. C. Zavala, M. Monick, and M. Brady. 1983. Role of interleukin-2 release by lung T-cells in active pulmonary sarcoidosis. Am. Rev. Respir. Dis. 128:634-638.

27. Semenzato, G., C. Agostini, L. Trentin, R. Zambello, M. Chilosi, A. Cipriani, E. Ossi, M. R. Angi, L. Morittu, and G. Pizzolo. 1984. Evidence of cells bearing interleukin-2 receptor at sites of disease activity in sarcoid patients. Clin. Exp. Immunol. 57:331-337.

28. Müller-Quernheim, J., C. Saltini, P. Sondermeyer, and R. G. Crystal. 1986. Compartmentalized activation of the interleukin 2 gene by lung $\mathrm{T}$ lymphocytes in active pulmonary sarcoidosis. J. Immunol. 137:3475-3483.

29. Saltini, C., J. R. Spurzem, J. L. Lee, P. Pinkston, and R. G. Crystal. 1986. Spontaneous release of interleukin 2 by lung T-lymphocytes in active pulmonary sarcoidosis is primarily from the leu3+ DR+ T-cell subset. J. Clin. Invest. 77:1962-1970.

30. Konishi, K., D. Moller, C. Saltini, M. Kirby, and R. Crystal. 1988. Spontaneous expression of the interleukin 2 receptor gene and presence of functional interleukin 2 receptors on $T$ lymphocytes in the blood of individuals with active pulmonary sarcoidosis. J. Clin. Invest. 82:775-781.

31. Keogh, B. A., G. W. Hunninghake, B. R. Line, and R. G. Crystal. 1983. The alveolitis of pulmonary sarcoidosis: evaluation of natural history and alveolitis-dependent changes in lung function. $\mathrm{Am}$. Rev. Respir. Dis. 128:256-265.

32. Saltini, C. A., J. Hance, V. J. Ferrans, F. Basset, P. B. Bitter- 
man, and R. G. Crystal. 1984. Accurate quantification of cells recovered by bronchoalveolar lavage. Am. Rev. Respir. Dis. 130:650-656.

33. Reynolds, H. Y., J. D. Fulmer, J. A. Kazmierowski, W. C. Roberts, M. M. Frank, and R. G. Crystal. 1977. Analysis of cellular and protein content of broncho-alveolar lavage fluid from patients with idiopathic pulmonary fibrosis and chronic hypersensitivity pneumonitis. J. Clin. Invest. 59:165-175.

34. Epstein, P. E., J. H. Dauber, M. D. Rossman, and R. P. Daniele. 1982. Bronchoalveolar lavage in a patient with chronic berylliosis: evidence for hypersensitivity pneumonitis. Ann. Intern. Med. 97:213216.

35. Moritz, E. D., O. P. Preuss, B. A. Keogh, and R. G. Crystal. 1982. Characterization of the alveolitis of beryllium-induced lung disease: similarities to pulmonary sarcoidosis. Am. Rev. Respir. Dis. 125(Part 2): 128.

36. Henry, C. 1980. Nylon wool. In Selected Methods in Cellular Immunology. B. B. Mishel and S. M. Shigi, editors. W. H. Freeman \& Co., Publishers, New York. 182-185.

37. Gillis, C., and J. Watson. 1980. Biochemical and biological characterization of lymphocyte regulatory molecules $\mathrm{V}$ : identification of an interleukin 2-producing human leukemia T-cell line. J. Exp. Med. 152:1709-1719.

38. Boylston, A. W., J. Borst, H. Yssel, D. Blanchard, H. Spits, and J. E. de Vries. 1986. Properties of a panel of monoclonal antibodies which react with the human $T$ cell antigen receptor on the leukemic line HPB-ALL and a subset of normal peripheral blood $\mathrm{T}$ lymphocytes. J. Immunol. 137:741-744.

39. Acuto, O., R. E. Hussey, K. A. Fitzgerald, J. P. Protentis, S. C. Meuer, S. F. Schlossman, and E. L. Reinherz. 1983. The human T cell receptor: appearance in ontogeny and biochemical relationship of $\alpha$ and $\beta$ subunits on IL-2 dependent clones and T cell tumors. Cell. 34:717-726.

40. Acuto, O., T. J. Campen, H. D. Royer, R. E. Hussey, C. B. Poole, and E. L. Reinherz. 1985. Molecular analysis of T cell receptor (Ti) variable region $(\mathrm{V})$ gene expression: evidence that a single $\mathrm{Ti} \beta$ gene family can be used in formation of $\mathrm{V}$ domains on phenotypically and functionally diverse T cell populations. J. Exp. Med. 161:13261343.

41. Chirgwin, J. M., A. E. Przybyla, R. J. MacDonald, and W. J. Rutter. 1979. Isolation of biologically active ribonucleic acid from sources enriched in ribonuclease. Biochemistry. 18:5294-5300.

42. Royer, H. D., A. Bensussan, O. Acuto, and E. L. Reinherz. 1984. Functional isotypes are not encoded by the contant region genes of the $\beta$ subunit of the $\mathrm{T}$ cell receptor for antigen/major histocompatibility complex. J. Exp. Med. 160:947-952.

43. Southern, E. M. 1975. Detection of specific sequences among DNA fragments separated by gel electrophoresis. J. Mol. Biol. 98:503-517.

44. Yoshikai, Y., D. Anatoniou, S. P. Clark, Y. Yanagi, R. Sangster, P. Van den Elsen, C. Terhorst, and T. W. Mak. 1984. Sequence and expression of transcripts of the human T-cell receptor $\beta$-chain genes. Nature (Lond.). 312:521-524.

45. Tiwari, J. L., and Terasaki, P. I. 1985. HLA and disease associations. Springer-Verlag New York, Inc., New York. 14-17.

46. Siu, G., E. C. Strauss, E. Lai, and L. E. Hood. 1986. Analysis of a human $\mathrm{V}_{\beta}$ gene subfamily. J. Exp. Med. 164:1600-1614.

47. Concannon, P., R. A. Gatti, and L. E. Hood. 1987. Human T-cell receptor $\mathrm{V}_{\beta}$ gene polymorphism. J. Exp. Med. 165:1130-1140. 48. Concannon, P., L. A. Pickering, P. Kung, and L. Hood. 1986.
Diversity and structure of human T-cell receptor $\beta$-chain variable region genes. Proc. Natl. Acad. Sci. USA. 83:6598-6602.

49. Kimura, N., B. Toyonaga, Y. Yoshikai, F. Triebel, P. Debre, M. D. Minden, and T. W. Mak. 1986. Sequences and diversity of human $\mathrm{T}$ cell receptor $\beta$ chain variable region genes. J. Exp. Med. 164:739-750.

50. Tillinghast, J. P., M. A. Behlke, and D. Y. Loh. 1986. Structure and diversity of the human T-cell receptor $\beta$-chain variable region genes. Science (Wash. DC). 233:879-883.

51. Bauer, W., M. K. Gorney, H. R. Baumann, and A. Morell. 1985. T-lymphocyte subsets and immunoglobulin concentrations in bronchoalveolar lavage of patients with sarcoidosis and high and low intensity alveolitis. Am. Rev. Respir. Dis. 132:1060-1065.

52. Rossi, G. A., O. Sacco, E. Cosulich, A. Risso, B. Balbi, and C. Ravazzoni. 1986. Helper T-lymphocytes in pulmonary sarcoidosis. Functional analysis of a lung T-cell subpopulation in patients with active disease. Am. Rev. Respir. Dis. 132:1086-1090.

53. James, D. G. 1983. Genetics and familial sarcoidosis. In Sarcoidosis and Other Granulomatous Diseases of the Lung. B. L. Fanburg, editor. Marcel Dekker, Inc., New York. 135-146.

54. Pinkston, P., P. Sarin, W. C. Saxinger, B. Hahn, R. Gallo, and R. G. Crystal. 1984. Evaluation of the human T-cell leukemia-lymphoma virus as a possible etiology of sarcoidosis. Am. Rev. Respir. Dis. 129:A21. (Abstr.)

55. Kappler, J. W., T. Wade, J. White, E. Kushnir, M. Blackman, J. Bill, N. Roehm, and P. Marrack. 1987. A T cell receptor V $\beta$ segment that imparts reactivity to a class II major histocompatibility complex product. Cell. 49:263-271.

56. Sredni, B., and R. H. Schwartz. 1980. Alloreactivity of an antigen-specific T cell clone. Nature (Lond.). 287:855-857.

57. Siliciano, R. F., T. J. Hemesath, J. C. Pratt, R. Z. Dintzis, H. M. Dintzis, O. Acuto, H. S. Shin, and E. L. Reinherz. 1986. Direct evidence for the existence of nominal antigen binding sites on $\mathrm{T}$ cell surface Ti $\alpha-\beta$ heterodimers of MHC-restricted T cell clones. Cell. 47:161-171.

58. Haskins, K., C. Hannum, J. White, N. Roehm, R. Kubo, J. Kappler, and P. Marrack. 1984. The antigen-specific, major histocompatibility complex-restricted receptor on T cells. J. Exp. Med. 160:452-471.

59. Governman, J., K. Minard, N. Shastri, T. Hunkapiller, D. Hansburg, E. Sercarz, and L. Hood. 1985. Rearranged $\beta$ T cell receptor genes in a helper $\mathrm{T}$ cell clone specific for lysozyme: no correlation between $\mathrm{V}_{\beta}$ and $\mathrm{MHC}$ restriction. Cell. 40:859-867.

60. Rupp, F., A.-O. Hans, H. Hengartner, R. Zinkernagel, and R. Joho. 1985. Identical $\mathrm{V}_{\beta} \mathrm{T}$-cell receptor genes used in alloreactive cytotoxic and antigen plus I-A specific helper T cells. Nature (Lond.). 315:425-427.

61. Barth, R. K., B. S. Kim, N. C. Lan, T. Hunkapiller, N. Sobieck, A. Winoto, H. Gershenfeld, C. Okada, D. Hansburg, I. L. Weissman, and $L$. Hood. 1985. The murine T-cell receptor uses a limited repertoire of expressed $V_{\beta}$ gene segments. Nature (Lond.). 316:517-523.

62. Acuto, O., R. E. Hussey, and E. L. Reinherz. 1985. Multiple class I and class II major histocompatibility complex allospecificities are generated with $\mathrm{T}$ cell receptor variable $(\mathrm{V})$ domains created by a single Ti $\beta$ V gene family. J. Exp. Med. 162:1387-1392.

63. Rupp, F., J. Brecher, M. A. Giedlin, T. Mosmann, R. M. Zinkernagel, H. Hengartner, and R. H. Joho. 1987. T-cell antigen receptors with identical variable regions but different diversity and joining region gene segments have distinct specificities but cross-reactive idiotypes. Proc. Natl. Acad. Sci. USA. 84:219-222. 